\title{
George Bernard Shaw's Androcles and the Lion: A Postmodernist Study
}

\author{
Noorbakhsh Hooti (Corresponding author) \\ Assistant professor, Razi University, Faculty of Arts \\ English Department, Kermanshah, Iran \\ Tel: 98-912-593-5460Ｅ-mail: nhooti@yahoo.com
}

\author{
Mojtaba Jeihouni \\ B A student of English Literature, Razi University, Faculty of Arts \\ English Departments, Kermanshah, Iran \\ Tel: 98-935-914-6901Ｅ-mail: jeihounimojtaba@yahoo.com
}

$\begin{array}{lr}\text { Received: October 17, } 2011 & \text { Accepted: October 27, } 2011 \quad \text { Published: April 1, } 2012 \\ \text { doi:10.5539/ies.v5n2p139 } & \text { URL: http://dx.doi.org/10.5539/ies.v5n2p139 }\end{array}$

\begin{abstract}
This study makes an attempt to analyze the manifold aspects of Shaw's Androcles and the Lion on a postmodernist standpoint, meanwhile, demonstrates the dominion of modernism, which is portrayed through the vehicle of comedy with a bitter ironic language through the play. Regardless of the historical period in which the play occurs, the term postmodernism with its lineaments can aptly scrutinize the clash between modernism and postmodernism, and define the notion of freedom in a world where man is in fetters, either physically or mentally or both at the same time. This study tries to show how two Christian prisoners find their way to freedom by resisting against the suppression and oppression of an empire, whose glory rests on silencing the opposing voices.
\end{abstract}

Keywords: Postmodernism, Metanarrative, Irony, Christianity, Belief

\section{Introduction}

This analytical paper has been prepared to display the struggling characters who interpret the meaning of life based on their purely hedonistic beliefs, and are the servants of various gods, and overall, are the slaves of their myopic metanarratives. They are the representatives of an aggressive idea which cannot stand a single opposition to what it claims and it harshly reacts to them in order to suppress their reforming voices. This postmodernist approach underlines the dominating modern values which rule the world and pretend to fulfill the utmost needs and expectations of the modern man, which is all in vain.

\section{Postmodernism}

Postmodernism has proved to be challenging for many scholars to define, and in fact it is not that easy to define, though in general, it can be said that postmodernism is a reaction against modernism. In the Dictionary of Literary Terms \& Literary Theory by Cuddon, postmodernism has been defined as, "A general (and sometimes controversial) term used to refer to changes, developments and tendencies which have taken place (and are taking place) in literature, art, music, architecture, philosophy, etc. since the 1940s or 1950s" (1999, p. 689). Postmodernism claims to be the successor of Enlightenment of modernism in which Rationality, Capitalism and Imperialism are its inseparable elements. Postmodernism came to existence at a point when mankind had experienced two devastating World Wars under the name of so-called rationality of modernism. It was born to show man a new way to save himself from the claws of imperialism, which is one of the legacies of modernism. Postmodernism covers vast realms of knowledge and attempts to specifically break down the human understanding through its own peculiar manner. According to Hooti \& Azizpour (2010):

"Postmodernism" is used to describe a wide gamut of aesthetic, cultural, historical, literary, and philosophical goings-on. It is often also used to suggest, variously, an eclectic style, a historical period, and a philosophical concept, as well as an anti-style, an atemporal event, and a non-concept. Often associated with deconstruction and poststructuralism, it is a term which undergoes uninterrupted redefinitions. In the visual arts and architecture, postmodernism is referred as pastiche or eclecticism. In philosophy, it stands against defining logocentrism and epistemological certainty that has characterized Western philosophy since Descartes. (p. 15)

The term postmodernism was first coined and popularized by the American literary critic Ihab Hassan, whose 
contribution to this new idea paved the way for the thinkers of his time such as Jean Baudrillard, Jacques Derrida, Michael Foucault, and Jean Francois Lyotard to cast a doubt over the legacies and fanaticism of modernism. It was after this period that man came to ponder and question the eligibility of the so- called rationality of modernism which had alienated human beings from their own existence. On this point, postmodernism alarms man and wake him up from the long existed slumber. It is then that he fearlessly stands against the fossilized metanarratives and breaks the shackles of the imposed restrictions. In the world of postmodernism, culture and the media play a crucial role in shaping people's identity. As Usher and Edwards comment, "In postmodernism, cultural practices and media are seen as having an unprecedented impact and a central role in framing sensibilities and identities." (1994, p. 13) The significant distinction that can be made between modernism and postmodernism is the emphasis of modernism merely on the "knowledge, giving the least importance to "morals", as the two barbarous world wars can be the apt justification to condemn modernism by leaving the world in the flood of blood. As a shocking force to react against such extreme notions, postmodernism comes into act and stands against all discriminations, which pose serious problems that lead to various mental pandemonium. In modernism "knowledge" holds the master key to solve the individual's problems, but postmodernism moves beyond this notion, as Seidman and Wagner state, "Postmodernism criticizes the modernist notion that science is or should be value-neutral; postmodernism underlines the practical and moral meaning of science." $(1992$, p. 7) The modern attitude towards prosperity and wealth are in the zenith of importance and we have no choice but to follow the idea which has been imposed on us, while in postmodernism it is otherwise and the spiritual needs of man is viewed with great love and passion. As Hooti \& Torkamaneh opine (2011), "In the world of Modernism achieving success has got the paramount importance. Individual is taught to be successful and gain success at any costs, while postmodernism believes in success, which is wedded to efficiency and merit." (p.1104)

To sum up postmodernism, it would be favorable to bear in mind the purpose of postmodernism in questioning the fossilized metanarratives and offering new methods to utilize suitable traditions combining them with the needs of the modern world in order to enjoy both.

\section{Literature and Postmodernism}

Postmodernism showed its effect on literature in the second half of the 20th century, when the writers criticized the modern world and its values through Beckettian absurdist ideology known as the theater of absurd. The term "theater of absurd" was first coined by British critic Martin Esslin, who introduced a new kind of theater under this title in 1962. To name a few of those writers who worked under this genre, are Sartre, Camus, Ionesco, Beckett, Albee, Pinter, Stoppard, who showed the meaninglessness of life in the world of modernism, a world where man found himself isolated and alienated. The most famous work and, probably, the most controversial absurdist play is Samuel Beckett's Waiting for Godot. The Characters of the play struggle to communicate with each other and are hopelessly waiting for the arrival of Godot, a Godot that never comes. The play precisely ends in the same condition it begins. The play tries to show the absurdity and hopelessness of human life and the helpless wait for a savior in the modern world. Indeed, creating the sense of dependence is one of the key elements of Modernism.

\section{George Bernard Shaw and Postmodernism}

George Bernard Shaw's chaotic, rebellious and reforming nature departs him from the calculative world of Modernism, as Bloom states, "Shaw's interest in margins and their problems - things excluded and included — links him to Jacques Derrida, who is preoccupied with the seemingly extraneous features in a text or ideology that subtly undermine its primary message." (2011, p. 48) As a prominent member of Fabian Society and an admirer of Ibsen, Shaw is a restless socialist who searches for a way to demonstrate the dark side of the society, and to do so he follows Ibsen's critical views on social issues by virtue of stage. Suleiman asserts (2010):

He regards the stage as a proper place to teach people since the previous Victorian playwrights said nothing about the bleak world the audience lived in. He admires Henrik Ibsen's plays since they touch greatness by sparking political and philosophical debate. Using the stage as a forum to cross-examine society, Ibsen shows Shaw how theater could serve ideal thoughts. (p. 11)

$\mathrm{He}$ is a writer who wastes no time to show his disagreement on social and political conventions and becomes a meticulous observer of society and its problems. His plays focus on the socio-political aspects of life. He is much concerned about the injustice, discrimination, starvation and destitution, which have covered the whole world like a fare well shroud. As Alexander asserts, "Shaw used the theater as a tool of social reform, presenting situations which challenged conventional attitudes, directing a stream of ideas at audiences, provoking while entertaining." (2000, p. 203). He is a prolific, though, controversial playwright, a committed socialist and one of those writers whose ability in ridiculing modern values of his day is deemed as one of the greatest ones. His use of comedy and his constant reproach of British society and social issues of modern world are evident in his all plays. As Griffith states, "His 
mastery of language allowed him to transform the most technical issues into accessible subjects for a general audience" (1993, p. 6).

\section{Androcles and the Lion}

Androcles and the Lion was an attempt made by Shaw to reproach the modern Christian churches and their rulers for misusing their power and manipulating public's beliefs to their own self-interest. The play was written in 1912 amid a period when the Christian Church had a substantial influence on society, and there was severe pressure on those, who held dissimilar beliefs. The different Christian characters throughout the play epitomize various types of Christian believers with different motivations and attitudes towards Christianity. Through the chain of events and the upshot of the play, each of the characters makes it clear which believers Shaw sympathizes with the most, especially with Lavinia whose isolation in the male dominated society is brilliantly depicted.

Lavinia: Perhaps you men will all go into heaven bravely and in triumph, with your heads erect and golden trumpets sounding for you. But I am sure I shall only be allowed to squeeze myself in through a little crack in the gate after a great deal of begging. (Shaw, 1912, p. 25-henceforth Shaw)

\section{Jacques Derrida and Deconstruction of Language}

French philosopher, Jacques Derrida is one of the pioneers of postmodernist movement, and more precisely post-structuralism. Derrida in 1967 introduced deconstruction, the most notable feature of post-structuralism as a new viewpoint to the principles of writing and its relation to philosophy. He tries to show that a piece of writing or speech can be interpreted in different ways and, therefore, there should be no hard-and-fast rules for different perceptions made on a text or speech, since terms do not have fixed meanings and may be applied involuntarily; as a result, they are context-dependent and what one receives may not be the same as what the other one does. He further emphasizes that language is metaphorical and a text has the potential to be approached in different ways. Robinson clarifies:

Language can never penetrate the inner meaning or pin down the 'essences' of concepts like 'truth' or 'knowledge'... Derrida is a critical of the belief that language can somehow prevent changes and fixed ideas, a belief that he calls 'logocentrity'. The conviction that language can generate stable and 'total' certainties is dangerous as well as misguided. Language can only be made to do this by repressing alternative readings or by excluding whatever is considered to be 'other'. Postmodernists like Derrida celebrate difference, diversity, and the marginal, those things that flourish in a pluralist and tolerant democracy. (qtd. in Hooti \& Azizpour, 2011, p. 22)

Derrida focuses that meaning may shift in different given times, so it is not the individual, who decides to stick to the fixed interpretations of the perceived ideas but the contextual needs of the current time, which are new and different from the time which has lost its presence. For Derrida text is not frozen in a single interpretation.

For Derrida, the passage to the limit, evoked by the Idea in the Kantian sense, takes the form not of a determinate, but of a nonfinite series of equivalent terms, as exemplified in the given sequence of nonequivalent terms. The passage to the limit as impossibility takes the form of just such an incomplete and incompletable series of non-equivalent, and radically dissimilar individual terms. (Hodge, 2007, p.73)

Derrida gives a beautiful differentiating interpretation of Text and Book, as Howell (1999) comments:

The 'book' is envisaged by Derrida as a fundamentally theological notions: Nature described as the book of God in the Middle Ages; the totalizing project of the eighteenth- century encyclopedia and of Hegel; the ideal book imagined by Leibniz in which every detail of life on earth since Creation would be found. In all these cases the book is conceived as totality, a meaningful whole, referring beyond itself to the 'real world', a volume heavy with meaning. The idea of book, Derrida writs, which always to a natural totality, is profoundly alien to the meaning of writing. It is the encyclopedic protection of theology and logocentrsm against the disruption of writing, against its aphoristic energy and... against difference in general.

Like philosophy, the book reassures us by its assumption of meaning, purpose and unity; it provides the most certain forgetfulness of death. The text, on the other hand, makes no claims to unity; it is heterogeneous and constituted by differences. The term 'text' suggests a woven texture, a cloth which is not transparent: A text is only a text if it hides at first sight, from the first-corner, the law of its composition and the rules of its games... The dissimulation of texture may in any case take centuries to unweave its cloth. (74)

\section{Jean Francois Lyotard and the fall of Grand Narratives}

The year 1979 was a milestone in the postmodernist movement, where the structure of postmodernism was molded 
by Jean Francois Lyotard in his philosophical masterpiece 'Postmodern Condition: A report on Knowledge; he defines postmodernism as "incredulity toward metanarratives". (1984, p. 24) He generalized beliefs about the world and their role in shaping human societies and examines how in different ways the basis and nature of knowledge have come under enormous changes in contemporary societies. He believes in the world of postmodernism, there is no need for the existence of metanarratives, which are nothing but the retarding and regressive forces that fasten the individual to the Presents of the Pasts, which are no more but mere memories of the fragmented moments. He argues that the grand-narratives that used to direct the course of knowledge and understanding have lost their authority in the postmodern world. The postmodern writer according to Lyotard (1984) is:

A postmodernist artist or writer is in the position of a philosopher: the text he writes, the work he produces are not in principle governed by pre-established rules, and they can not be judged according to a determining judgment, by applying familiar categories to the text or to the work. Those rules and categories are what the work of art itself is looking for. The artist and the writer, then, are working without rules in order to formulate the rules of what will have been done. (p. 81)

Androcles and the Lion can be regarded as a play in which metanarratives serve as an unchangeable approach towards life and their immeasurable effects on society. These metanarratives are given specific attention to enable the rulers to tyrannically suppress individuals, who eagerly and adamantly insist on innovative notions. Shaw yells his voice against all the socio-cultural and religious notions, which are apprehensive to accept any modifications, which are the inevitable needs of the existing world generation.

\section{Irony}

Comedy arises mostly from societies, where there is immense pressure and censorship on writers and they are prevented from directly talking about social evils of present day, instead, they make indirect and covert criticism of the injustice, cruelty, poverty, social gaps of the society through the vehicle of comedy and laughter. The term irony in The Concise Oxford Dictionary of Literary Terms by Baldick has been put forward as, "A subtly humorous perception of inconsistency, in which an apparently straightforward statement or event is undermined by its context so as to give it a very different significance."(2001, p. 130) Through the play the utilization of irony to discuss serious social matters is tangible. On the prologue, when

Megaera is fed up with her husband's obstinacy to remain a Christian and not doing what the majority does, she shows her fury of his eccentricity:

Megaera: What can you do! You can return to your duty, and come back to your home and your friends, and sacrifice to gods as all respectable people do, instead of having us hunted of house and home for being dirty, disreputable, blaspheming atheists.

Androcles: I am not an atheist, dear: I am a Christian. (Shaw, p. 5)

Being the slaves of several gods was a tradition, which existed and still exists as a result of myopia; it caused man to fear anybody under his invention of such a term as "gods" to give life and authority to the so-called creators he himself created through his imagination. This theme of idolatry is manifest throughout the play and as soon as Androcles and Megaera come across the lion, Megaera, being very terrified, criticizes Androcles of being a Christian and his defiance on not obeying gods, because she attributes this incident to the rage of gods:

Megaera: (despairing) The gods have sent him to punish us because you are a Christian. (p. 7)

In the words of The Captain there is a conviction which shows the Emperor as a perfect individual who is always free from conviction:

The Captain: (unmoved and somewhat sardonic) Persecution is not a term applicable to the acts of the Emperor. The Emperor is the Defender of the Faith. In throwing you to the lions he will be upholding the interests of religion in Rome. If you were to throw him to the lions, that would no doubt be persecution. (p.

12)

The everlasting recurrent use of the term "interest" that is used by authorities to justify their cruelty and suppression over the opposing beliefs, which even have become more frequent since 20th century, makes the rulers perfect and free in their convictions and verdicts. The Captain afflicted by such notions is offended by Megaera and asserts that the Emperor's actions are all fine and are free from defects, since he is the Emperor and this makes him flawless and impeccable.

The Captain: From the skies? Do not deceive yourself, Lavinia. There is no future for you beyond the grave.

Lavinia: What does that matter? Do you think I am only running away from the terrors of life into the 
comfort of heaven? If there were no future for me, or if the future were one of torment, I should have to go just the same. The hand of God is upon me. (p. 17)

In the modern world there is no future after death for humans, since modern rationality and science are unable to justify through scientific experiments the existence of such a world. This belief is shown in Act I, when the existence of a next world is denied by the Captain and; therefore, he sees Lavinia's belief about such an issue a self-deception.

On Act II, when the Christians are visited by the Emperor, Lavinia makes a direct and sharp criticism at the Emperor's suppressing manners, which is retorted by Metellus who makes it clear that the Emperor is perfect:

Lavinia: Blessing, Caesar, and forgiveness!

Caesar: (turning in some surprise at the salutation) There is no forgiveness for Christianity.

Lavinia: I did not mean that, Caesar. I mean that we forgive you.

Metellus: An inconceivable liberty! Do you not know, woman, that the Emperor can do no wrong and therefore can not be forgiven?

Lavinia: I expect the Emperor knows better. Anyhow, we forgive him.

The Christians: Amen! (p. 35)

Metellus, being aware of the fact that Ferrovius' presence in the Emperor guards would trouble their misuse of power, emphasizes that conscience has no place in their empire:

Caesar: Metellus: I should like to have this man in the Pretorian guard.

Metellus: I should not, Caesar. He looks a spoilsport. There are men in whose presence it is impossible to have any fun: men who are a sort of walking conscience. He would make us all uncomfortable. (p. 36)

The Centurion talking with contempt and humiliation to Ferrovius, says, "Now remember that you are a Christian, and that you've got to return good for evil."(p.19) This shows his awareness of Christianity and his misuse of Ferrovius' beliefs to rule and dominate him: "That's the way to manage them!" (p. 19)

At the end of the play, Ferrovius secures a place in the Emperor's guards but goes back in his beliefs. Lavinia rejects The Captain's offer to become a member of the Empire and directly points her criticism to Ferrovius, who has lost his belief in God and has sold his soul:

The Captain: What do you say, Lavinia? Will you too be prudent?

Lavinia: (on the stair) No: I'll strive for the coming of God who is not yet. (p. 54)

\section{Conclusion}

In a world where hypocrisy, misuse of power, and the race to gain pleasure at any cost become the ultimate goals of mankind, people become slaves under the lash of modernism and have no choice but to obey the inviolable rules of modernism. As Shaw maintains on the epilogue:

People who are shown by their inner light the possibility of a better world based on the demand of the spirit for a nobler and more abundant life, not for themselves at the expense of others, but for everybody, are naturally dreaded and therefore hated by the Have-and-Holders. (p.55)

In a postmodern world people can freely express their own views and notions and choose their own choices without the apprehension of any possible impending jeopardy awaiting them. This study was an attempt to show how a logocentric source of judgment, which believes to be the sole legitimate decision making faculty is doomed to fail. This sense of logocentrism can be of any metanarrative categories, which different superpowers under different pretexts use them to rule over their helpless nations. Hence the sole Godot of an individual is nobody else but the individual himself. Indeed, understanding one's rights and fighting for them without any apprehension can shake and loosen the pillars of the logocentric authorities, who find the nations as the inherited slaves.

\section{References}

Alexander, Michael. (2000). A History of English Literature. London: Macmillan Press LTD.

Baldick, Chris. (2001). The Concise Oxford Dictionary of Literary Terms. New York: Oxford University Press.

Bloom, Harold. (2011). Bloom's Modern Critical Views: George Bernard Shaw- New Edition. New York: Infobase Publishing.

Cuddon, J. A. (1999). Dictionary of Literary Terms \& Literary Theory. (4th ed.) London: Penguin Books. 
Griffith, Gareth. (1993). Socialism and Superior Brains: The Political Thought of Bernard Shaw. London: Routledge.

Hodge, Joanna. (2007). Derrida on Time. New York: Routledge.

Hooti, Noorbakhsh \& Azizipour, Farzaneh. (2010). Arthur Miller's Death of a Salesman: A postmodernist Study. Studies in Literature and Language, 8(1) 15-28.

Hooti, Noorbakhsh \& Azizpour, Farzaneh. (2011). Sense of Isolation in Arthur Miller's All my Sons: A Postmodernist Study. Cross Cultural Communication, 7(1) 17-31

Hooti, Noorbakhsh \& Torkamaneh, Pouria. (2011). Henrik Ibsen's A Doll House: A Postmodernist Study. Theory and Practice in Language Studies, 9(1). http://dx.doi.org/10.4304/tpls.1.9.1103-1110

Howells, Christina. (1999). Derrida: Deconstruction from Phenomenology to Ethics Cambridge: polity Press

Lyotard, Jean Francois. (1984). The Postmodern Condition: A Report on Knowledge. Geoff Bennington and Brian Massumi (Trans.). Minneapolis: University of Minnesota Press.

Seidman, Steven \& Wagner, David G. (1992). Postmodernism and Social Theory. Massachusetts: Basil Blackwell.

Shaw, George Bernard. (1912). Androcles and the Lion. Pennsylvania: Pennsylvania State University.

Suleiman, Azher. (2010). George Bernard Shaw. Suleiman. [Online] Available: http://www.pdffactory.com (September 25, 2011)

Usher, Robin \& Edwards, Richard. (1994). Postmodernism and Education. London: Routeldge 